\title{
Substituting corn grain for passion fruit peels in feed for confined sheep
}

\author{
Substituição do grão de milho pela casca de maracujá na alimentação de ovinos \\ confinados
}

${ }^{1 *}$ PAZDIORA, Raul Dirceu

https://orcid.org/0000-0002-5495-4737

${ }^{1}$ PAZDIORA, Bruna Rafaela Caetano

Nunes

https://orcid.org/0000-0002-5262-0514

${ }^{1}$ QUEIROZ, Edicarlos Oliveira

https://orcid.org/0000-0002-5821-7152

${ }^{2}$ MENDONÇA, Talita Oliveira

https://orcid.org/0000-0001-6739-7071
${ }^{3}$ CÂNDIDO, Fernanda dos Santos

https://orcid.org/0000-0001-7663-231X

${ }^{4}$ ANJOS, Mariana Moreira dos https://orcid.org/0000-0003-3798-1503

${ }^{3}$ MATOS, Islan Junior Rodrigues de https://orcid.org/0000-0001-7681-202X

${ }^{3}$ ANDRELINO, André Luiz Silva https://orcid.org/0000-0002-6328-8756

${ }^{1}$ Fundação Universidade Federal de Rondônia, Campus de Presidente Médici, Departamento de Zootecnia, Presidente Médici, Rondônia, Brasil

${ }^{2}$ Universidade Estadual Paulista "Júlio de Mesquita Filho", Faculdade de Ciências Agrárias e Veterinárias - Campus de Jaboticabal, Pós-graduação em Medicina Veterinária, Jaboticabal, São Paulo, Brasil;

${ }^{3}$ Fundação Universidade Federal de Rondônia, Campus de Rolim de Moura, Departamento de Medicina Veterinária, Rolim de Moura, Rondônia, Brasil;

${ }^{4}$ Fundação Universidade Federal de Rondônia, Campus de Rolim de Moura, Pós-graduação em Agroecossistemas Amazônicos, Rolim de Moura, Rondônia, Brasil;

*Mail for correspondence: raul.pazdiora@unir.br

\section{ABSTRACT}

The aim of this study was to evaluate diets substituting corn grain with passion fruit peels on the consumption, ingestive behavior, digestibility of diets and sheep performance. A total of 20 sheep were used, confined in individual pens, fed twice a day, with diets which included passion fruit peels in the proportions of $0 ; 25 ; 50 ; 75$ and $100 \%$ replacing corn grain. The corn grain represented $70 \%$ of the dry matter of the diet and the passion fruit peels were supplied in dehydrated form. The experimental design was completely randomized with five treatments and four replicates. The data were submitted to analysis of variance and regression analysis at the significance level of 5\%. There was a linear increase in dry matter consumption with an increase of $3.89 \mathrm{~g}$ for each inclusion level of passion fruit peel. The apparent digestibility of dry matter decreased and neutral detergent 
fiber increased linearly with the substitution of corn grain with passion fruit peels. The feeding, rumination, leisure and water intake times presented averages of $3.74 ; 2.92$; 16.92 and 0.42 hours, and were not influenced by the diets $(\mathrm{P}>0.05)$. The average daily weight gain was similar for the animals in the different diets and consequently the final weight presented average values of $0.226 \mathrm{~kg}^{-1 a y}{ }^{-1}$ and $32.1 \mathrm{~kg}$, respectively. The inclusion of passion fruit peels in the sheep diet is an interesting alternative because even with the reduced dry matter digestibility, it increased the consumption and promoted similar weight gains.

Keywords: Non-conventional foods. Productive performance. Ovinoculture. Intensive system. Ruminant.

\section{RESUMO}

Objetivou-se avaliar dietas com substituição do grão de milho pela casca de maracujá sobre o consumo, comportamento ingestivo, digestibilidade das dietas e desempenho de ovinos. Foram utilizados 20 ovinos, confinados em baias individuais, alimentados duas vezes ao dia, com dietas que receberam a inclusão da casca de maracujá nas proporções de $0 ; 25 ; 50 ; 75$ e $100 \%$ em substituição ao grão de milho. O grão de milho representou $70 \%$ da matéria seca da dieta e a casca de maracujá foi fornecida na forma desidratada. $\mathrm{O}$ delineamento experimental foi inteiramente casualizado, com cinco tratamentos e quatro repetições. Os dados foram submetidos à análise de variância e análise de regressão, ao nível de 5\%. Observou-se um aumento linear do consumo de matéria seca, com acréscimo de 3,89 g para cada nível de inclusão de casca de maracujá. A digestibilidade aparente da matéria seca reduziu e a fibra detergente neutro aumentou linearmente com a substituição ao grão de milho pela casca de maracujá. O tempo de alimentação, ruminação, ócio e ingestão de água, com médias de 3,74; 2,92; 16,92 e 0,42 horas, não foram influenciados pelas dietas $(\mathrm{P}>0,05)$. $\mathrm{O}$ ganho de peso médio diário foi semelhante para os animais nas diferentes dietas e por consequência o peso final, apresentando valores médios de $0,226 \mathrm{~kg} \mathrm{dia}^{-1}$ e $32,1 \mathrm{~kg}$, respectivamente. A inclusão de casca de maracujá na dieta de ovinos é uma alternativa interessante, pois mesmo com a redução da digestibilidade da matéria seca, aumentou o consumo e promoveu semelhante ganho de peso.

Palavras-chave: Alimentos não convencionais. Desempenho produtivo. Ovinocultura. Sistema intensivo. Ruminante.

\section{INTRODUCTION}

Sheep farming in Brazil has ceased to be only used as production for family survival and has become of great importance at the commercial level (Gonzaga et al., 2018). Data provided by the Brazilian Institute of Geography and Statistics (IBGE, 2019a) show that sheep production reached 18.9 million head with a density of 0.02 head per hectare in 2018, showing an increase in relation to the last few years. Rondônia presented a herd of 95,202 heads this year, which represents $0.50 \%$ of the total animals, and demonstrates that the production chain needs to be better organized to reach the State's productive potential. 
Regarding sheep feed, much of the country, including the state of Rondônia, has a seasonal rainfall regime which causes grasses to present $80 \%$ of their yield in the six wettest months of the year, causing a harvest and off-season in livestock dependent on pastures. The other six months have a low forage availability and nutritional value (Cruz et al., 2013).

Among the alternatives to "optimize" animal production, one can consider the use of agro-industrial waste as a way to reduce production costs with food. According to Lousada Jr. et al. (2006), waste is generated in significant quantities from the field to the fruit processing industry, and it is estimated that 45 to $50 \%$ of the total production is waste.

Cruz et al. (2013) and Sena et al. (2015) presented the use of fruit processing residues as an alternative food form, particularly during the dry season, causing a reduction in food costs. Passion fruit (Passiflora edulis $\mathrm{f}$. Flavicarpa) production is widely distributed geographically, with Brazil being the largest producer (IBGE, 2017), and its peel is the main residue. Rondônia occupies the $17^{\text {th }}$ position among Brazilian states in area destined to harvest (527 hectares) and is the third largest producer $(3,889$ tons $)$ in the North behind Pará and Amazônia (IBGE, 2019b). Thus, studies on its nutritional value are important (Cruz et al., 2011), as it has a low acquisition cost and its alternative use can reduce the effects of environmental impact (Couto Filho et al., 2010).

Dehydrated passion fruit peels can be supplied in an incorporated or natural way in feeding ruminants (Cruz et al.,
2011). Its good nutritional value and acceptability by the animals was verified by Pazdiora et al. (2019), and characterizes it as a possible substitute for conventional foods such as corn kernels, reducing feed costs. In addition, the lignin level in the cell wall is important to hinder access by microorganisms and therefore preserve the stability of the rumen environment (Silva et al., 2013).

In this context, the objective of this study was to evaluate using passion fruit peels in diets with different corn grain substitution levels on consumption, ingestive behavior, diet digestibility and performance of confined sheep.

\section{MATERIAL AND METHODS}

This study was carried out on a commercial property located on line 192 , $\mathrm{km} 08$, south side, in the municipality of Rolim de Moura, RO, Brazil, and occurred between the months of October and December 2018. The region's climate is Am type according to the Koppen-Geiger classification, therefore being an equatorial climate with variation between hot and humid tropical, with well-defined dry season (June/September), minimum average temperature of $24^{\circ} \mathrm{C}$, maximum average $32^{\circ} \mathrm{C}$ and average of $28^{\circ} \mathrm{C}$. The average annual precipitation is $2,250 \mathrm{~mm}$.year ${ }^{-1}$ with high relative air humidity of around 85\% (Alvares et al., 2013).

A total of 20 male sheep aged $6 \pm 1$ months, with an initial weight of $19.5 \pm$ $3.7 \mathrm{~kg}$, previously treated against ecto and endoparasitosis (ivermectin active ingredient) were used. The sheep were confined in individual stalls of $1 \mathrm{~m}^{2}$ with slatted wooden floors and contained 
individual feeders and drinkers. Each treatment consisted of four animals, with each sheep corresponding to an experimental unit. This project was submitted to the Ethics Committee on the Use of Animals (CEUA), Faculty of Biomedical Sciences of Cacoal (FACIMED), and approved for execution according to protocol number PP $008 / 2017$ on $07 / 31 / 2017$.
Mineral supplementation was included in the diet and the tested treatments were: diet without passion fruit peel (control) and diets with 25; 50; 75 and 100\% substitution of corn grain by dehydrated passion fruit peels. It is worth mentioning that the corn grain represented $70 \%$ of the dry matter (DM) of the diet (Table 1).

Table 1. Composition of diets with substitution levels of corn grain for passion fruit peels provided to confined sheep.

\begin{tabular}{lccccc}
\hline \multirow{2}{*}{ Ingredients, $\%$} & \multicolumn{5}{c}{ Substitution levels of corn grain for passion fruit peels, $\%$} \\
\cline { 2 - 6 } & 0 & 25 & 50 & 75 & 100 \\
\hline Corn grain & 70.0 & 52.5 & 35.0 & 17.5 & 0.0 \\
Passion fruit peel & 0.0 & 17.5 & 35.0 & 52.5 & 70.0 \\
Livestock Urea & 1.0 & 0.9 & 0.8 & 0.6 & 0.5 \\
Soybean meal & 14.0 & 14.1 & 14.2 & 14.4 & 14.5 \\
Mineral Salt & 3.0 & 3.0 & 3.0 & 3.0 & 3.0 \\
Elephant Grass & 12.0 & 12.0 & 12.0 & 12.0 & 12.0 \\
\hline Total & 100.0 & 100.0 & 100.0 & 100.0 & 100.0 \\
\hline
\end{tabular}

The residue from extracting passion fruit pulp from small agro-industrial producers in the municipality of Rolim de Moura, RO and region was used for this study, being properly dehydrated until the moisture content was below $15 \%$, as periodically verified by taking a sample to the greenhouse to monitor the moisture content. The peels were dehydrated in the sun in a cemented area, being spread in layers of approximately $7 \mathrm{~cm}$ thick and turned at least three times a day. After drying the peels, they were crushed in a forage crusher adjusted to form a similar average particle size to crushed corn for later inclusion in the diets.

The elephant grass was dehydrated before beginning the experimental period, thus enabling storage and to maintain nutritional quality during supply to the animals. It was cut with an average height of 1.20 meters, crushed in a forage crusher and exposed to the sun. After drying, it was stored for later supply to the animals.

The passion fruit peels used in the diet formulations presented $13.4 \%$ of crude protein $(\mathrm{CP}), 0.21 \%$ of ether extract (EE), $9.7 \%$ of mineral matter (MM), $11.8 \%$ of non-fibrous carbohydrates (NFC), 64.9\% neutral detergent fiber (NDF), $45.3 \%$ acid detergent fiber (ADF), 28.4\% cellulose, $19.5 \%$ hemicellulose and $16.9 \%$ lignin. The diets were formulated to be isoprotein (Table 2) and offered in an amount which would allow leftovers of approximately $10 \%$ of what was originally offered. Water was available 
ad libitum for all animals, which was renewed daily in the morning with cleaning of drinking fountains.

Table 2. Chemical composition of diets with substitution levels of corn grain for passion fruit peels provided to confined sheep.

\begin{tabular}{lccccc}
\hline \multirow{2}{*}{\multicolumn{1}{c}{ Nutrients. \% }} & \multicolumn{5}{c}{ Substitution levels of corn grain for passion fruit } \\
& 0 & 25 & 50 & 75 & 100 \\
\cline { 2 - 6 } & 90.2 & 89.2 & 89.4 & 89.5 & 89.2 \\
\hline Dry matter (DM) & 18.9 & 19.0 & 19.5 & 18.9 & 20.0 \\
Crude protein (CP) & 0.62 & 0.63 & 0.52 & 0.57 & 0.43 \\
Ether extract (EE) & 23.9 & 29.6 & 40.1 & 45.0 & 59.6 \\
Neutral detergent fiber (NDF) & 7.0 & 8.0 & 8.8 & 11.1 & 10.4 \\
Mineral material (MM) & 49.9 & 42.9 & 30.7 & 24.6 & 9.8 \\
Non-fibrous carbohydrates & & & & & \\
(NFC) & & & & & \\
\hline
\end{tabular}

The dry matter consumption (DMC) was evaluated daily using an electronic digital scale by the difference in weight between the food supplied and the leftovers. This procedure made it possible to calculate the consumption of MM, CP, EE, NDF and NFC. The dry matter consumption in relation to body weight (DMC/BW) was determined by the DMC divided by the average weight of the animal and subsequently multiplied by 100 .

Feed conversion (FC) was determined through the relationship between the $\mathrm{DMC}$ and the average daily weight gain (ADG). ADG was measured by the difference in the sheep's weight at the beginning and at the end of the experimental period, divided by the number of days elapsed (56 days). The evaluation period started 15 days after adaptation. The animals were weighed using a digital scale and after a 14-hour fast of solids.

The ingestive behavior of the sheep was observed and recorded over a period of 48 consecutive hours on the $28^{\text {th }}$ and $29^{\text {th }}$ days after the end of the adaptation period. Behavioral observations were performed directl, with instantaneous recording and focal and timed sampling. The interval between samplings was adopted every $5 \mathrm{~min}$ by two independent observers in a relay system, strategically positioned so as not to disturb the animals. The evaluation shift for each pair of observers was 6 hours. The following parameters were evaluated: feeding time, rumination time, leisure time and water intake time. In addition, 5 observations were made every 6 hours of evaluation to assess the number of chews per bolus and the time chewed per bolus. Feeding and ruminating efficiency (expressed in $\mathrm{g} \mathrm{DM} \mathrm{h}^{-1}$ and $\mathrm{g} \mathrm{NDF} \mathrm{h}^{-1}$ ) was obtained by dividing the average daily DM and NDF consumption by the total time spent on feeding and/or ruminating in 24 hours, respectively. The environment was maintained with artificial lighting during data collection at night. The data were recorded in specific spreadsheets.

The total feces collection method was 
used for three consecutive days to estimate the dry matter (DMAD) and nutrient (MMAD, CPAD, EEAD and NDFAD) apparent digestibility coefficients, with the first day of collection being the $40^{\text {th }}$ day after the end of the adaptation period. Feces were collected immediately after excretion to avoid contact with urine. The digestibilities are expressed as a percentage, being calculated using the equation: [(DM or nutrients ingested $(\mathrm{g})$ - DM or nutrients in feces $(\mathrm{g}) /(\mathrm{DM}$ or nutrients ingested) $(\mathrm{g})] * 100$.

Collected samples of the food, leftovers and feces were dried in an oven at $55^{\circ} \mathrm{C}$ for $72 \mathrm{~h}$ to determine the dry matter in air. Next, they were ground in a Willey mill, sieved with $1 \mathrm{~mm}$ sieves and stored in plastic pots, and then later sent for analysis to the laboratory for products of plant and animal origin (Laprova) at the Alta Mogiana Regional Polo, Colina, SP. The DM was determined in an oven at $105^{\circ} \mathrm{C}$ for 24 hours and the ash content (mineral matter) was determined by combustion at $550^{\circ} \mathrm{C}$ for 4 hours (Silva \& Queiroz, 2002).

Total nitrogen was determined by the Kjeldahl method (Method 984.13, AOAC, 1995). The NDF and ADF determinations were performed following the guidelines of Komarek (1993) and the EE was determined by hot extraction $\left(90^{\circ} \mathrm{C}\right)$ for 90 minutes with petroleum ether in a Goldfish extractor (AOAC, 1995). The NFC content was estimated by the equation: $100-(\mathrm{CP}+$ $\mathrm{EE}+\mathrm{MM}+\mathrm{NDF})$. The $72 \% \mathrm{w} / \mathrm{w}$ sulfuric acid method was used to determine "Klason" lignin (Silva \& Queiroz, 2002). Hemicellulose (HEM) and cellulose (CEL) were calculated using equations: $\mathrm{HEM}=\mathrm{NDF}-\mathrm{ADF}$ and $\mathrm{CEL}=\mathrm{ADF}-$ lignin.

The experimental design was completely randomized with five treatments and four replications. The data were submitted to the normality test (Shaphiro-Wilk test), analysis of variance, polynomial contrasts and regressions (linear, quadratic and cubic), using the Statistical Analysis System (SAS) statistical software package at 5\% significance. The model chosen in the regression analysis was the one which best fit the obtained data.

\section{RESULTS AND DISCUSSION}

The DMC and DMC/BW increased linearly as the passion fruit peel was included in the diet, with an increase of $3.89 \mathrm{~g}$ and $0.018 \%$ for each inclusion level, respectively (Table 3). In evaluating different residues in the sheep diet such as cupuaçu (seed), acerola (seeds), pineapple (peel and crown), passion fruit (peel) and tifton hay (control diet), Pazdiora et al. (2019) observed that the DMC was higher for animals that received passion fruit residue (1170.6 $\left.\mathrm{g} \mathrm{day}^{-1}\right)$ than for those that received tifton hay $\left(962.7 \mathrm{~g} \mathrm{day}^{-1}\right)$ and with much more than the animals that received cupuaçu (452.9 $\left.\mathrm{g} \mathrm{day}^{-1}\right)$, acerola (644.2 $\mathrm{g} \mathrm{day}^{-1}$ ) and pineapple (693.8 $\left.\mathrm{g} \mathrm{day}^{-1}\right)$ residues, all of which were supplied in a $75 \%$ proportion of the diet. The authors justified the difference in consumption by the chemical composition of the residues, mainly NDF, which has a variation in the proportions of cellulose, hemicellulose and lignin, as it influences the acceptability, digestibility, time and ruminal transit of this diet. In view of 
the diet a high energy value, reaching $24.98 \%$ (Lousada Jr. et al., 2006). In this way, the degradation of the fibrous fraction of the diet in comparison to the corn grain, rich in starch, can also provide an ideal rumen environment (Henrique et al., 2003). In addition to NDF, the composition of this fiber is also important as it may contain a high proportion of lignin, which in addition to being indigestible also negatively interferes in the cellulose digestibility by making ruminal bacterial action unfeasible (Oliveira et al., 2013).

In using $75 \%$ of residues in the sheep diet, Pazdiora et al. (2019) found that DMAD was higher for the diet with passion fruit $(77.85 \%)$ in relation to the diets with pineapple $(63.14 \%)$, acerola $(59.07 \%)$ and cupuaçu (61.68\%), and similar to the diet with tifton hay (71.83\%). Furthermore, in evaluating pineapple, guava, papaya, mango and passion fruit residues for substituting corn silage in the proportions of 10 and
30\%, Azevedo et al. (2011) found similarity in digestibility between diets with $10 \%$ substitution, while at $30 \%$ there was a significant effect on digestibility. Pineapple and papaya residues had a higher DMAD $(\mathrm{p}<0.05)$ at the $30 \%$ inclusion level in the diets compared to those of guava and passion fruit. The justifications in both works are related to the variation in the chemical composition of the residues, mainly to the lignin content, and to the DMC.

The apparent digestibility of CP, EE and MM were not influenced due to the substitution of corn grain by passion fruit peels for confined sheep. There is greater use of these nutrients by animals with greater $\mathrm{CP}$ and $\mathrm{MM}$ consumption and similar digestibility. According to Cruz et al. (2011), digestibility is influenced by the feed level, the ruminal capacity and the chemical composition of the diets, while the ruminal retention time may vary.

Table 4. Apparent digestibility of dry matter and nutrients in diets with inclusion levels of passion fruit peels substituting corn grain supplied to confined sheep.

\begin{tabular}{|c|c|c|c|c|c|c|c|c|c|}
\hline \multirow{2}{*}{$\begin{array}{c}\text { Variables }^{1} \text {, } \\
\%\end{array}$} & \multicolumn{5}{|c|}{$\begin{array}{l}\text { Substitution levels of corn grain for } \\
\text { passion fruit peels, } \%\end{array}$} & \multirow{2}{*}{$\begin{array}{c}\mathrm{CV}^{2} \\
\%\end{array}$} & \multicolumn{3}{|c|}{ Regression $^{3}$} \\
\hline & 0 & 25 & 50 & 75 & 100 & & $\mathrm{~L}$ & $\mathrm{Q}$ & $\mathrm{C}$ \\
\hline DMAD & 83.8 & 76.3 & 76.3 & 74.7 & 71.5 & 3.07 & $<0.0001^{4}$ & 0.1468 & 0.0282 \\
\hline CPAD & 81.5 & 78.9 & 81.9 & 82.1 & 83.7 & 3.39 & 0.1258 & 0.3077 & 0.3635 \\
\hline EEAD & 44.9 & 46.9 & 63.0 & 60.6 & 46.6 & 24.8 & 0.4528 & 0.0694 & 0.2450 \\
\hline MMAD & 67.9 & 62.0 & 59.7 & 68.6 & 65.8 & 8.19 & 0.7992 & 0.1107 & 0.0952 \\
\hline NDFAD & 44.8 & 43.8 & 62.4 & 60.1 & 68.4 & 14.8 & $0.0012^{5}$ & 0.8926 & 0.5394 \\
\hline
\end{tabular}

${ }^{1} \mathrm{DMAD}=$ Dry matter apparent digestibility; CPAD $=$ Crude protein apparent digestibility; EEAD $=$ Ether extract apparent digestibility; MMAD = Mineral matter apparent digestibility; NDFAD = Neutral detergent fiber apparent digestibility.

${ }^{2} \mathrm{CV}=$ coefficient of variation.

${ }^{3} \mathrm{~L}=$ linear, $\mathrm{Q}=$ quadratic and $\mathrm{C}=$ cubic.

Equations: ${ }^{4} \mathrm{DMAD}=80.51470-0.08360 \mathrm{X}\left(\mathrm{R}^{2}=0.59\right) ;{ }^{5} \mathrm{NDFAD}=39.40118+0.30828 \mathrm{X}\left(\mathrm{R}^{2}=0.67\right)$

Studying the ingestive behavior is an important tool in evaluating diets, as it enables adjusting the feeding management of animals to obtain better 
productive performance (Figueiredo et al., 2013). The feeding, rumination, leisure and water intake times presented averages of $3.74 ; 2.92 ; 16.92$ and 0.42 hours, and were not influenced by the diets (Table 5), even though the chemical composition, mainly the NDF contents were different. When observing the feeding time, in which the NDF varied between 23 and $60 \%$, it is observed that the time used did not change. A possible explanation for this could be due to the size of the particles being the same, since the passion fruit peels were crushed so that the particles were similar to the crushed corn grain, and thus did not change the physical effectiveness of the fibers.

Table 5. Ingestive behavior of sheep fed the inclusion of passion fruit peels as a substitute for corn grain for confined animals

\begin{tabular}{|c|c|c|c|c|c|c|c|c|c|}
\hline \multirow{2}{*}{ Variables $^{1}$} & \multicolumn{5}{|c|}{$\begin{array}{l}\text { Substitution levels of corn grain } \\
\text { for passion fruit peels, } \%\end{array}$} & \multirow{2}{*}{$\begin{array}{l}\mathrm{CV}^{2} \\
, \%\end{array}$} & \multicolumn{3}{|c|}{ Regression $^{3}$} \\
\hline & 0 & 25 & 50 & 75 & 100 & & $\mathrm{~L}$ & Q & $\mathrm{C}$ \\
\hline $\mathrm{FT}, \mathrm{h}$ & 4.37 & 3.70 & 3.40 & 3.76 & 3.49 & 22.4 & 0.2170 & $0.36^{\circ}$ & 0.46 \\
\hline $\mathrm{RT}, \mathrm{h}$ & 3.35 & 3.03 & 3.02 & 2 & 2.94 & 28.8 & 25 & 0.70 & S. \\
\hline $\mathrm{LT}, \mathrm{h}$ & 15.8 & 16.8 & 17.1 & 17.6 & 17.1 & 6.27 & 0.0522 & 0.1517 & 0.7345 \\
\hline DT, h & 0.47 & 0.45 & 0.46 & 0.40 & 0.47 & 59.2 & 0.6035 & 0.5647 & 0.3055 \\
\hline NCB, no. & 59.0 & 60.0 & 60.9 & 56.5 & 61.2 & 15.5 & 0.9450 & 0.9038 & 0.5331 \\
\hline CTB, s & 42.1 & 46.7 & 45.9 & 37.7 & 44.1 & 16.4 & 0.6604 & 0.7685 & 0.0939 \\
\hline FEDM, g MS h ${ }^{-1}$ & $\begin{array}{c}213 . \\
4\end{array}$ & 291.7 & 379.8 & 383.5 & 483.6 & 21.3 & $0.0004^{4}$ & 0.7927 & 0.4787 \\
\hline REDM, g MS h ${ }^{-1}$ & $\begin{array}{c}289 . \\
3\end{array}$ & 366.0 & 435.4 & 636.0 & 515.3 & 24.1 & $0.0031^{5}$ & 0.2642 & 0.0988 \\
\hline FENDF, $\mathrm{g} \mathrm{MS} \mathrm{h}^{-1}$ & 29.8 & 53.0 & 132.6 & 158.0 & 282.9 & 19.7 & $<0.0001^{6}$ & 0.0139 & 0.2998 \\
\hline RENDF, $\mathrm{g} \mathrm{MS} \mathrm{h}{ }^{-1}$ & 37.7 & 67.2 & 152.0 & 262.0 & 301.5 & 23.1 & $<0.0001^{7}$ & 0.5779 & 0.0598 \\
\hline
\end{tabular}

${ }^{1} \mathrm{FT}=$ feeding time; $\mathrm{RT}=$ rumination time; $\mathrm{LT}=$ leisure time; $\mathrm{DT}=$ drinking water time; $\mathrm{NCB}=$ number of chews per bolus; CTB = chewing time per bolus; FEDM = feed efficiency as a function of dry matter consumption; REDM = rumination efficiency as a function of dry matter consumption; FENDF $=$ feeding efficiency as a function of neutral detergent fiber consumption; RENDF = rumination efficiency as a function of neutral detergent fiber consumption;

${ }^{2} \mathrm{CV}=$ coefficient of variation. ${ }^{3} \mathrm{~L}=$ linear, $\mathrm{Q}=$ quadratic and $\mathrm{C}=$ cubic.

Equations: ${ }^{4} \mathrm{FEDM}=238.21153+2.29721 \mathrm{X}\left(\mathrm{R}^{2}=0.57\right) ;{ }^{5} \mathrm{REDM}=291.44271+3.35289 \mathrm{X}\left(\mathrm{R}^{2}=0.48\right)$; ${ }^{6} \mathrm{FENDF}=10.11542+2.32228 \mathrm{X}\left(\mathrm{R}^{2}=0.86\right) ;{ }^{7} \mathrm{RENDF}=15,05102+2.98180 \mathrm{X}\left(\mathrm{R}^{2}=0.87\right)$;

$\mathrm{DM}$ and NDF feeding efficiencies increased linearly with the substitution of corn grain by passion fruit peels, where there was an increase of 2.30 and $2.32 \mathrm{~g} \mathrm{DM} \mathrm{h}^{-1}$ at each substitution level, respectively. In relation to feeding efficiency, there was no effect of the inclusion of passion fruit peel on the time spent in feeding in hours per day, so the linear increases in the DM and NDF consumption caused the sheep that received higher passion fruit peel levels in the diet ingested greater amounts of DM and NDF at similar feeding times. 
This explains the improvement in DM or NDF feed efficiency (expressed in g) per hour. Figueiredo et al. (2019) also did not observe any difference between the average times spent feeding when evaluating the inclusion of $0,12,24$ and $36 \%$ of passion fruit in replacing tifton 85 grass hay in feeding crossbred heifers, even showing a difference of NDF in the composition of diets.

It was observed that the rumination time was not influenced by including passion fruit peels in the sheep diet. An increase in rumination times was expected due to the higher NDF consumption by sheep with the inclusion of passion fruit peel (Azevedo et al., 2013). However, some other aspects need to be considered such as the NDF composition and the physically effective NDF, which can influence the indigestibility degree of the $\mathrm{NDF}$, which in turn is evaluated by the particle size, the content of potentially degradable fiber and the degradation rate of this fiber in the rumen.

The number of chews per bolus and time of chews per bolus were not influenced by including passion fruit peel in the sheep diet, with the number of chews bolus $^{-1}$ being between the ranges of 56.5 to 61.2 , respectively, and the time of chews being 37.7 to $46.7 \mathrm{~s}^{\text {bolus }}{ }^{-1}$, possibly caused by the similar particle size in the diets, resulting in the same effectiveness of the fiber. Cirne et al. (2014) found a similar rumination time for lambs fed with mulberry hay in the proportions of $0 ; 12.5$ and $25 \%$ in replacing the concentrate, justified by the same fiber content in diets. In addition, the mulberry hay was crushed using a 0.8 $\mathrm{mm}$ mesh sieve to facilitate standardizing the concentrates and to avoid selectivity by the lambs.
The rumination DM and NDF efficiencies increased linearly with the inclusion of passion fruit peel, with increases of 3.35 and $2.98 \mathrm{~g} \mathrm{~h}^{-1}$ of DM and NDF, respectively, for each increase in passion fruit peel, demonstrating to be more efficient in ruminating. These increases in efficiencies are associated with higher DMC and NDF consumption and similar total rumination time, chew time and number of chews per ruminated bolus. Carvalho et al. (2014) relate that the NDF content contained in the food and the particle size are important factors which influence the animals' ingestive behavior. The greater the amount of NDF and/or the larger particle size, the greater the time spent on chewing activities (feeding and ruminating), which can influence the ability to eat food. In the present study, the crushing of the dehydrated passion fruit peels reduced the NDF effectiveness, which explains the results.

ADG was not influenced by the substitution of corn grain by passion fruit peels, presenting an average of $0.225 \mathrm{~kg}$ day $^{-1}$, and as a consequence the animals presented similar final weight with an average of $32.1 \mathrm{~kg}$, thus presenting slaughtering conditions by weight reached (Table 6). The NRC (1985) recommends gains of $300 \mathrm{~g}$ day $^{-1}$, suggested for highly specialized breeds for meat production; however, the ADG is affected by the breed, sex, and age of the animal, and mainly by the diet characteristics to which it was submitted. Costa et al. (2011) obtained gains in the order of $204.2 \mathrm{~g} \mathrm{day}^{-1}$ when evaluating the performance of Santa Inês, Dorper $\mathrm{x}$ Santa Inês and Sem Breed sheep receiving a diet with $50 \%$ roughage and $50 \%$ concentrate. According to the 
present study, gains of $225 \mathrm{~g} \mathrm{day}^{-1}$ can be considered satisfactory with the use of fruit residues. In evaluating lambs from 12 to $25 \mathrm{~kg}$ of body weight using dehydrated cashew bagasse or sorghum silage as the roughage source, Silva et al. (2011) found similarities in weight gain with gains of $117.55 \mathrm{~g} \mathrm{day}^{-1}$ for the lambs that received cashew bagasse.

Table 6. Sheep performance fed the inclusion of passion fruit peels as a substitute for the corn grain supplied to confined sheep.

\begin{tabular}{|c|c|c|c|c|c|c|c|c|}
\hline \multirow[t]{2}{*}{ Variables } & \multicolumn{5}{|c|}{$\begin{array}{l}\text { Substitution levels of corn grain for } \\
\text { passion fruit peels, } \%\end{array}$} & \multirow{2}{*}{$\begin{array}{l}\mathrm{CV}^{1} \\
\%\end{array}$} & \multicolumn{2}{|c|}{ Regression $^{2}$} \\
\hline & 0 & 25 & 50 & 75 & 100 & & Q & $\mathrm{C}$ \\
\hline Initial weight, kg & 19.0 & 19.4 & 19.1 & 19.7 & 20.1 & 21.1 & $0.7067 \quad 0.9080$ & 0.9446 \\
\hline Final weight, kg & 31.8 & 30.8 & 33.2 & 33.1 & 31.4 & 15.5 & $0.8764 \quad 0.7001$ & 0.5494 \\
\hline $\mathrm{ADG}, \mathrm{kg}$ & 0.229 & 0.204 & 0.251 & 0.238 & 0.200 & 18.0 & $0.7430 \quad 0.2962$ & 0.1620 \\
\hline $\mathrm{FC}$ & 4.16 & 4.77 & 5.10 & 5.94 & 6.88 & 16.8 & $0.0006^{3} \quad 0.5148$ & 0.8023 \\
\hline $\begin{array}{l}\text { ADG }=\text { average daily } \\
\mathrm{FC}=\text { feed conversion } \\
{ }^{1} \mathrm{CV}=\text { coefficient of } \\
\text { Equation: }{ }^{3} \mathrm{FC}=4.20 \\
\text { The ADG show } \\
\text { including passic } \\
\text { associated with th } \\
\text { resulted in worse } \\
\text { increase in the va } \\
\text { inclusion level. } \\
\text { found that the } \\
\text { observed in anim }\end{array}$ & $\begin{array}{l}\text { on no } \\
\text { ed frui } \\
\text { e increa } \\
\text { ning th } \\
\text { lues of } \\
\text { azdiora } \\
\text { est FC }\end{array}$ & $\begin{array}{l}42 \mathrm{X}\left(\mathrm{R}^{2}\right. \\
\text { nanges } \\
\text { peel } \\
\text { e in th } \\
\mathrm{FC} \text {, v } \\
024 \mathrm{f} \\
\text { et al. } \\
\text { values }\end{array}$ & $\begin{array}{l}0.47 \text { ) } \\
\text { when } \\
\text { and } \\
\text { DMC } \\
\text { h an } \\
\text { each } \\
019) \\
\text { were }\end{array}$ & matt & $\begin{array}{l}\text { revents } \\
\text { assion } \\
\text { educes } \\
\text { ddition, } \\
\text { n region } \\
\text { his resi } \\
\text { educe } p\end{array}$ & $\begin{array}{l}\text { inar } \\
\text { fruit } \\
\text { envir } \\
\text { it wil } \\
\text { ss whe } \\
\text { due ea }\end{array}$ & $\begin{array}{l}\text { mal feed feasibl } \\
\text { ropriate dispos } \\
\text { eels and consec } \\
\text { nmental pollutic } \\
\text { enable sheep proc } \\
\text { e it is possible to } \\
\text { ily, thus contribu } \\
\text { n costs. }\end{array}$ & $\begin{array}{l}\text { e and } \\
\text { al of } \\
\text { uently } \\
\text { n. In } \\
\text { uction } \\
\text { obtain } \\
\text { ing to }\end{array}$ \\
\hline
\end{tabular}
passion fruit (8.3) and tifton hay (13.4) in relation to acerola (56.4), and similar to the animals that received pineapple (18.4) and cupuaçu (31.7). The authors explained these differences due to the chemical composition, which influenced the consumption and use of nutrients. Including passion fruit peels as a substitute for corn grain linearly increases the consumption and efficiency of dry matter feeding, which shows good acceptance by the sheep and decreases the dry matter apparent digestibility. The inclusion of passion fruit peels does not interfere with the average daily gain and final weight for confined sheep, which therefore makes

\section{ACKNOWLEDGEMENTS}

The authors would like to thank the Federal University of Rondônia Foundation (UNIR) for granting the Scientific Initiation scholarships (PIBIC/UNIR). 


\section{REFERENCES}

ALVARES, C.A.; STAPE, J.L.; SENTELHAS, P.C; GONÇALVES, J.L. de; SPAROVEK, G. Koppen's climate classification map for Brazil. Meteorologische Zeitschrisft, v. 22, n. 6, p. 711-728, 2013.

ALVES, A.R.; PASCOAL, L.A.F.; CAMBUÍ, G.B.; TRAJANO, J. da S.; SILVA, C.M. da; GOIS, G.C. Fibra para ruminantes: Aspecto nutricional, metodológico e funcional. Pubvet, v. 10, n. 7, p. 568-579, 2016.

\section{ASSOCIATION OF OFFICIAL} ANALYTICAL CHEMISTRY AOAC. Official methods of analysis. 16. ed. Arlington: AOAC International, 1995. $1025 \mathrm{p}$.

AZEVEDO, R.A.; RUFINO, L.M.A.; SANTOS, A.C.R.; RIBEIRO JUNIOR, C.S.; RODRIGUEZ, N.M.; GERASEEV, L.C. Comportamento ingestivo de cordeiros alimentados com torta de macaúba. Arquivo Brasileiro de Medicina Veterinária e Zootecnia, v. 65, n. 2, p. 490-496, 2013.

CARVALHO, S.; DIAS, F.D.; PIRES, C.C.; BRUTTI, D.D.; LOPES, J.F.; SANTOS, D.; BARCELOS, R.D.; MACARI, S.; WOMMER, T.P.; GRIEBLER, L. Comportamento ingestivo de cordeiros Texel e Ideal alimentados com casca de soja.

Archivos de Zootecnia, v. 63, n. 241, p. 55-64, 2014.

CIRNE, L.G.A.; SILVA SOBRINHO, A.G da; SANTANA, V.T.; SILVA, F.U.; LIMA, N.L.L.; OLIVEIRA, E.A. de; CARVALHO, G.G.P.de; ZEOLA, N.M.B.L.; TAKAHASHI, R.

Comportamento ingestivo de cordeiros alimentados com dietas contendo feno de amoreira. Semina: Ciências Agrárias, v. 35, n. 2, p. 1051-1060, 2014.

COSTA, Q.P.B.; WECHSLER, F.S.; COSTA, D.P.B.; POLIZEL NETO, A.; ROÇA, R.O.; BRITO, T.P.

Desempenho e características da carcaça de bovinos alimentados com dietas com caroço de algodão. Arquivo Brasileiro de Medicina Veterinária e Zootecnia. v. 63, n. 3, p. 729-735, 2011.

COUTO FILHO, C.C.D.C.; SILVA FILHO, J.C. da; NEIVA JUNIOR, A.P.; SOUZA, R.M. de; NUNES, J.A.R.; COELHO, J.V. Frações fibrosas da silagem de resíduo de manga com aditivos. Ciência e Agrotecnologia, v. 34, n. 3, p. 751-757, 2010.

CRUZ, B.C.C.; CRUZ, C.L. dos S.; PIRES, A.; ROCHA, J.B.; BASTOS, M.P.V.; SANTOS, S. Desempenho, consumo e digestibilidade de cordeiros em confinamento recebendo silagens de capim elefante com diferentes proporções de casca desidratada de maracujá. Semina: Ciências Agrárias, v. 32, n. 4, p. 1595-1604, 2011.

CRUZ, S.S.; MORAIS, A.B.F.; RIBEIRO, S.B.; OLIVEIRA, M.G. de; COSTA, M.S. da; FEITOSA, C.T.L. Resíduos de frutas na alimentação de ruminantes. Revista Eletrônica

Nutritime, v. 10, n. 6, p. 2909-2931, 2013. 
FIGUEIREDO, M.P. de; SALIBA, E. de O.S.; BARBOSA, G.S.S.C.; AGUIAR E SILVA, F.; MOTA E SILVA, C.R. da; NUNES, A.N.; MOREIRA, G.R.; MARTINS, L.T. Passion fruit by-product as a substitute for Tifton 85 hay in diets for dairy heifers. Semina: Ciências Agrárias, v. 40, n. 6, p. 2719-2732, 2019.

FIGUEIREDO, M.R.P.; SALIBA, E.O.S.; BROGES, I.; REBOUÇAS, G.M.N.; AGUIAR E SILVA, F.; SÁ, H.C.M. Comportamento ingestivo de ovinos alimentados com diferentes fontes de fibra. Arquivo Brasileiro de Medicina Veterinária e Zootecnia, v. 65, n. 2, p. 485-489, 2013.

GONZAGA, S.S.; CORREAA, G.F.; SANTOS, L.V. dos; IRIGOYEN, L.R.; SCHEEREN, F.B. Manual de cortes de carne ovina: para um melhor aproveitamento da carcaça. Embrapa, Brasília-DF, 2018.

HENRIQUE, W.; SAMPAIO, A.A.M.; LEME, P.R.; ALLEONI, G.F.; LANNA, D.P.D., MALHEIROS, E.B. Digestibilidade e balanço de nitrogênio em ovinos alimentados à base de dietas com elevado teor de concentrado e níveis crescentes de polpa cítrica peletizada. Revista Brasileira de Zootecnia, v. 32, n. 6, p. 2007-2015, 2003.

INSTITUTO BRASILEIRO DE GEOGRAFIA E ESTATÍSTICA IBGE. Produção agrícola municipal 2017. Rio de Janeiro: IBGE, 2017. Disponível em: $<$ https:// sidra.ibge.gov.br/pesquisa/pam/tabelas> . Acesso em: 04 novembro 2019.
INSTITUTO BRASILEIRO DE GEOGRAFIA E ESTATÍSTICA IBGE. Produção da pecuária municipal 2019. Rio de Janeiro: IBGE, 2019a. Disponível em: $<$ https://sidra.ibge.gov.br/tabela/3939>. Acesso em: 01 junho 2020.

INSTITUTO BRASILEIRO DE GEOGRAFIA E ESTATÍSTICA IBGE. Produção da pecuária municipal 2019. Rio de Janeiro: IBGE, 2019b. Disponível em:

$<$ https://www.ibge.gov.br/estatisticas/ec onomicas/agricultura-e-pecuaria/9117producao-agricola-municipal-culturastemporarias-epermanentes.html $?=\& \mathrm{t}=$ resultados $>$. Acesso em: 06 janeiro 2021.

KOMAREK, A.R. A filter bag procedure for improved efficiency of fiber analysis. Journal of Dairy Science, v. 76, suppl. 1, 250-259, 1993. LOUSADA JÚNIOR, J.E.; COSTA, J.M.C. da; NEIVA, J.N.M.; RODRIGUEZ, N.M. Caracterização físico-química de subprodutos obtidos do processamento de frutas tropicais visando seu aproveitamento na alimentação animal. Revista Ciência Agronômica, v. 37, n. 1, p. 70-76, 2006.

NATIONAL RESEARCH COUNCIL NRC. Nutrient requirementsof sheep. 6.ed. Washington, D.C.: National Academy Press, 1985. 99p.

OLIVEIRA, R.L.; LEÃO, A.G.; ABREU, L.L.; TEIXEIRA, S.; SILVA, T.M. Alimentos alternativos na dieta de ruminantes. Revista Científica de 
Produção Animal, v. 15, n. 2, p. 141160, 2013. .

PAZDIORA, R.D.; PAZDIORA, B.R.C.N.; FERREIRA, E.; MUNIZ, I.M.; ANDRADE, E.R.; SIQUEIRA, J.V.S.; SCHERER, F.; VENTUROSO, O.J.; SOUZA, P.J. Digestibilidade, comportamento ingestivo e desempenho de ovinos alimentados com resíduos de agroindústrias processadoras de frutas.

Arquivo Brasileiro de Medicina Veterinária e Zootecnia, v. 71, n. 6, p. 2093-2102, 2019.

SENA, J.A.B.; VILLELA, S.D.J.; SANTOS, R.A.; PEREIRA, I.G.; CASTRO, G.H.F.; MOURTHÉ, M.H.F.; BONFÁ, C.S.; MARTINS, P.G.M.A. Intake, digestibility, performance, and carcass traits of ramsprovided with dehydrated passion fruit (Passiflora edulis f. flavicarpa) peel, as a substitute of Tifton 85 (Cynodon spp.). Small Ruminant Research, v. 129, p. 18-24, 2015.

SILVA, D. J.; QUEIROZ, A. C. Análise de alimentos: métodos químicos e biológicos. 3. ed. Viçosa, MG: Editora UFV, 2002. 235 p.

SILVA, L.M.; OLIVEIRA, C.H.A.; RODRIGUES, F.V.; RODRIGUES, M.R.C.; BESERRA, F.J.; SILVA, A.M.; LEMOS, J.C.; FERNANDES, A.A.O.; RONDINA, D. Desempenho e características da carcaça de cordeiros alimentados com bagaço de caju.

Archivos de Zootecnia, v. 60, n. 231, p. 777-786, 2011.

SILVA, R.H.P.; SOUSA, B.M.de;

SILVA NETA, C.S.; INÁCIO, D.F. da S.; MUNIZ, T.M.P. Utilização de subprodutos na alimentação de bovinos leiteiros em minas gerais. Revista Eletrônica Nutritime, v. 10, n. 6, p. 2962-2981, 2013. 